\title{
Social Media and EuroMaidan: A Review Essay
}

\author{
Megan MacDuffee Metzger and Joshua A. Tucker
}

As more than a billion people had done previously, on November 21, 2013, Ukrainian journalist and activist Mustafa Nayem wrote a Facebook post; this post, however, would have a much larger impact on subsequent political developments than most that had preceded it. ${ }^{1}$ Frustrated with President Viktor Yanukovych's decision not to sign a long-promised association agreement with the European Union, Nayem asked others who shared his frustration to comment on his post. Even more importantly, Nayem wrote that if the post received at least 1000 comments from people willing to join him, they should all go to Independence Square to protest. And indeed they did: starting with just a few thousand people, the protests would swell to be the largest since Ukraine's independence, particularly after police used force against protesters at the end of November 2013. Eventually, these protests led to the resignation of the government, the exile of the former president, and indirectly to the secession of Crimea and the ongoing conflict in the eastern part of the country. ${ }^{2}$

While we are of course not claiming that Nayem's original post was the sole cause of all that followed for Ukraine, the EuroMaidan protests may be the first where we can point directly and unambiguously to social media as a pivotal moment of organization. During the protests there was a large degree of speculation about the exact role of social media as they continued. While a number of journalistic and blog accounts have described the uses of social media during the protests, scholarly research, on the other hand, is still emerging.

The purpose of this review, therefore, is threefold. First, we aim to provide a comprehensive summary of what is known to date about the usage of social media during the EuroMaidan protests. That being said, there is relatively little published academic work on the topic-perhaps not surprisingly given the pace at which academic publishing (in marked contrast to social media!) generally proceeds-and therefore we supplement our review with information from blog posts, journalists, and our own interviews and data analysis. ${ }^{3}$ Second, we seek to ground this assessment in existing social science theoretical

1. Both authors contributed to the design and arguments of the article, as well as the revision and editing of the manuscript. Metzger wrote the first draft and conducted the review of the literature.

2. As we complete the final edits on this article, this pattern of protest springing from a single Facebook post has once again been replicated in the January 21, 2017 Women's March, only this time the post in question was written not by a known activist or journalist, but rather "a grandmother in Hawaii," at www.washingtonpost.com/national/ it-started-with-a-grandmother-in-hawaii-now-the-womens-march-on-washington-ispoised-to-be-the-biggest-inauguration-demonstration/2017/01/03/8af61686-c6e2-11e6bf4b-2c064d32a4bf_story.html (last accessed January 25, 2017).

3. The data analysis was conducted using data from the New York University Social Media and Political Participation (SMaPP) lab (https://wp.nyu.edu/smapp/), where Tucker is a Co-Director and Metzger a Graduate Research Associate. 
work related to the phenomenon of political protest. Finally, we hope to combine extant theory from the social sciences and recent evidence from Ukraine to propose a forward-looking research agenda that will improve understanding of the role of social media in the EuroMaidan protests specifically, the role of social media in protest movements more generally, and how to harness the unique opportunities presented by the fact that much of social media usage is digitally archived and therefore available for scholarly analysis.

To very quickly define terms, we use the term social media to refer to platforms that allow users to both generate and share content within networks of people who have chosen to utilize these platforms, as well as (in many instances) to form specific ties with other users, either in uni-directional, oneto-one ("follower") relationships such as on Twitter, bi-directional, one-to-one ("friends") relationships such as on Facebook, or by joining larger groups that may or may not be private (such as on Facebook or VKontakte).4 "Digital media" includes social media, but also includes more traditional websites that may or may not be static.

The essay proceeds as follows. We turn first to the existing theoretical literature to identify potential mechanisms by which social media could impact both protest development at the macro-level and protest participation at the micro-level. We then provide some background on the evolution of digital media in Ukraine from the Orange Revolution up to the EuroMaidan protests, as well as outline the way the EuroMaidan protests progressed. Against this background, we then explore the literature to date on the role of social media during the EuroMaidan protests. In the final part of the essay, we highlight a path forward for future research by outlining a number of important remaining questions.

\section{Social Media, Protest, and Social Movements}

In assessing the role that social media may have played during the EuroMaidan protests, it is important to consider the mechanisms by which we might expect social media to affect the development of protest. The natural starting point here is to conceptualize social media as a way citizens can receive information that they can utilize in deciding whether or not to participate in a protest. The availability of information, the way it spreads, and its relationship to the individual protest decision is critical to most social science theories of protest. The way information is received and the structure of the information environment can alter the dynamics of dissent and the opportunities that emerge. ${ }^{5}$ The availability of information can inform

4. Examples of social media platforms include Facebook, Twitter, VKontakte, and Instagram. At the edge of this definition lies a number of platforms that are designed to facilitate communication between select groups of individuals such as Facebook Messenger, iMessenger, Snapchat, What's App, YikYak, and Zello, but which do not really involve creating content so much as sending messages. See also Robert Ackland, Web Social Science: Concepts, Data, and Tools for Social Scientists in the Digital Age (London, 2013).

5. Herbert Kitschelt, "Political Opportunity Structures and Political Protest: AntiNuclear Movements in Four Democracies," British Journal of Political Science 16, no. 1 (January 1986): 57-85. 
people's decision to protest and their expectations about the behavior of others. ${ }^{6}$ Finally, the way information is framed can alter the perception of the protests and change the dynamics of how they are viewed by both potential supporters and opponents. ${ }^{7}$

Social media could affect the informational environment surrounding a protest movement in a number of important ways. Prior to the advent of digital media, we might expect potential protesters to receive information in one of several ways including: by word of mouth; by seeing flyers or announcements specifically drawn up to publicize protests; or by hearing about protests through traditional media sources such as newspapers or television. Such information sources are (a) largely local (with the exception of international news channels such as $C N N$, RT, or Al Jazeera) and (b) largely hierarchical (with the exception of word of mouth). In addition, traditional media always has the possibility of being controlled by the state, or by actors close to the state, especially in authoritarian or competitive-authoritarian regimes. ${ }^{8}$

So how do social media change this traditional information environment? First, they create a networked space for the exchange of information that is not geographically bounded. Social media allow information to be spread to anyone who has access to the Internet (or access to someone else who has access to the information). ${ }^{9}$ Individual "word of mouth" information can now be spread to hundreds or thousands of people simultaneously without having to be physically proximate or involved in a telephone conversation. Egyptians can learn about developments in Tunisia regardless of whether Egyptian state television chooses to cover Tunisian protests.

Second, social media greatly reduce the explicit hierarchy inherent in traditional media environments. ${ }^{10}$ The networked space described above also allows all users to be both recipients and creators of information. This is particularly important in situations in which the mainstream media is either partially or completely controlled by the state. Where every protestor can also function as a small-scale journalist, there are opportunities to circumvent government censorship-which can allow individuals to frame their own narratives-and to engage with the mainstream media as participants

6. Mark Grannovetter, “The Strength of Weak Ties,” American Journal of Sociology 78, no. 6 (May 1973): 1360-80; Timur Kuran, "Now out of Never: The Element of Surprise in the East European Revolutions of 1989," World Politics 44, no. 1 (October 1991): 7-48; Susanne Lohmann, "Dynamics of Informational Cascades: The Monday Demonstrations in Leipzig, East Germany, 1989-1991,” World Politics 47, no. 1 (October 1994): 42-101.

7. David A. Snow and Robert D. Benford, "Master Frames and Cycles of Protest," in Aldon Morris and Carol McClurg Mueller, eds., Frontiers in Social Movement Theory (New Haven, 1992), 133-55.

8. Steven Levitsky and Lucan Way, Competitive Authoritarianism: Hybrid Regimes After the Cold War (New York, 2010).

9. In the ongoing debate about the importance of social media during the Arab Spring, one detail that often gets neglected is the fact that flyers circulated on Facebook would then be printed and distributed by hand, providing an example of the indirect ways in which social media can distribute information. Jesse Drew, A Social History of Contemporary Democratic Media (New York, 2013).

10. Note that this does not imply that there is no hierarchy of information on social media, only that the explicit hierarchies inherent in the structure of traditional media are no longer as evident. 
in a conversation rather than simply passive recipients of information. It is worth speculating whether this process of participating in creating the actual content used for organization might make more people feel a sense of "ownership" over the movement, and consequently provides a reservoir for greater commitment to the cause over time. This is in contrast to the arguments that some have made that online action makes people feel as though they have done something without actually having participated in ways that create durable networks of activism. ${ }^{11}$

Finally, all of these dynamics are occurring at speeds that are exponentially faster than anything that preceded social media. A picture uploaded in real time from a protest can instantly be viewed by anyone with access to the Internet anywhere in the world (subject to the poster's own privacy settings and the platform they use to share the content). Not only can it be viewed anywhere in the world, but it can also be viewed by any potential protester in the city where the protest is taking place, or elsewhere in the country where protests might conceivably be organized. It can be seen in villages where people may be considering coming to the city to join the protest, or even in neighboring countries where people may see that a protest is actually taking place before the national media in their own country can establish a narrative that no such protests are occurring.

It is also worth reiterating that this information in many cases comes not simply from a flier encountered on a street sign, but rather from co-workers, colleagues, family, and friends from all walks of life. This is not to say that misinformation cannot be spread in this way, or that trusted friends cannot pass along information that could turn out to be nothing more than rumor in retrospect. ${ }^{12}$ Information received through these networks, however, can contain additional cues (based on the source of information) that may help users evaluate its importance or validity, thus rendering the information potentially more useful.

Beyond transmitting information, social media has the capacity to affect the dynamics of mobilization and organization. Resource mobilization theories, as well as other structural theories, have suggested that organizations and civil society, or being connected to a network of other activists (still usually mediated at some point by more formal organizations), are critical to organizing and sustaining protest. ${ }^{13}$ These theories are in fact based on the idea that organizations are the primary, if not the only, way in which

11. Malcolm Gladwell, "Small Change: Why the Revolution Will Not be Tweeted," New Yorker, October 4, 2010, at www.newyorker.com/magazine/2010/10/04/small-changemalcolm-gladwell (last accessed May 10, 2016).

12. Again to comment as we prepare the final version of this manuscript for publication, the subject of misinformation-and social media's role in spreading misinformation-has been elevated in importance due to more recent developments; this remains an important subject for future research beyond the scope of the current article.

13. J. Craig Jenkins, "Resource Mobilization Theory and the Study of Social Movements," Annual Review of Sociology 9 (1983): 527-53; John McCarthy and Mayer Zald, "Resource Mobilization and Social Movements: A Partial Theory," American Journal of Sociology 82, no. 6 (May 1977): 1212-41. On other structural theories see: Hanspeter Kriesi, "Political Context and Opportunity," in David Snow, Sarah Soule, and Hanspeter Kriesi, eds., The Blackwell Companion to Social Movements, (Oxford, 2004), 67-90; Douglas 
protests are organized. Social media potentially changes the dynamics of this process, because individuals are in more constant connection with all of the overlapping networks in which they are embedded. Perhaps under these conditions, tightly organized groups are less important than the activation of existing networks of similar individuals for promoting protest. Once protest is underway, a similar argument might be made about how protest is sustained, how discipline is maintained, or how the material needs of the protest are met.

Finally, we can think about the impact of social media on the persistence of social movements and protest networks over time. Some critics of social media have argued that because social media networks are less consolidated, and less unified, that they will not develop into durable organizations that can contribute to the development of civil society or towards the creation of parties following the end of protests. ${ }^{14}$ Others, for example Lance Bennet and Alexandra Segerberg, have argued that while movements with a substantial social media component may not develop into the traditional organizations that we expect, they may also simply represent a new structure of organization and participation which may ultimately be similarly effective. ${ }^{15}$

In the following sections, we will outline the existing evidence about how social media seems to have played a role in the EuroMaidan protests via each of these channels: providing organizational tools; facilitating the spread of information; and contributing to the persistence of social movements and protest networks. We begin, however, by providing some background.

\section{Digital Media, Ukraine, and Ukrainian Politics}

The use of social media in the EuroMaidan protests did not happen in a technological vacuum. Indeed, digital technology had played an important role in Ukraine's previous major political upheaval, the 2004 Orange Revolution. Nor did the causes motivating the EuroMaidan protests emerge suddenly in late 2013. Therefore, we provide some background in this section on the use of digital technology in the Orange Revolution, the evolving digital media environment in Ukraine since the Orange Revolution, and a brief summary of the events that led to the EuroMaidan protests.

McAdam, "Recruitment to High-Risk Activism: The Case of Freedom Summer," American Journal of Sociology 92, vol. 1 (July 1986): 64-90.

14. Gladwell, "Small Change"; Evgeny Morozov, The Net Delusion: The Dark Side of Internet Freedom (New York, 2011).

15. W. Lance Bennet and Alexandra Segerberg, “The Logic of Connective Action: Digital Media and the Personalization of Contentious Politics," Information, Communication \& Society 15, no.5 (June 2012); See as well work by Barberá et al., who put forward an argument about the relative importance of even peripheral members of protest networks online playing a crucial role in the spread of information about the protest. Pablo Barberá, Ning Wang, Richard Bonneau, John T. Jost, Jonathan Nagler, Joshua Tucker and Sandra González-Bailón, “The Critical Periphery in the Growth of Social Protests," PLoS ONE 10, no.11 (November 2015), at www.journals.plos.org/plosone/article?id=10.1371/journal. pone.0143611 (last accessed January 10, 2017). 


\section{The Orange Revolution and the History of Digital Media in Ukrainian Protest}

The Euromaidan movement was the second large-scale protest movement in Ukraine since the country became independent. The first, known as the Orange Revolution, took place in late 2004 in response to reports of widespread electoral fraud in the presidential election. The protests lasted until early 2005, involved hundreds of thousands of people, and were organized with the help of opposition political parties. Eventually, they resulted in a third round of elections that brought Viktor Yuschenko to power.

Michael McFaul has argued, "The Orange Revolution may be the first in history to be organized largely online." 16 While the Orange Revolution predated the rise of social media, digital media (particularly the Internet and mobile phones) played a key role both in making the protests possible and in coordinating them once they began. Joshua Goldstein points out that over the years preceding the Orange Revolution, opposition activists had become tech savvy and begun to develop online networks. ${ }^{17}$ Groups such as "Maidan" created online spaces for discourse along with organizing offline trainings in election observation. Similarly, "Pora" was a youth organization geared at ensuring democratic elections in 2004. One of Pora's key activities was education and the dissemination of accurate information in the highly censored media environment that existed in Ukraine at the time. While this included an enormous door to door and in-person campaign, the organization also used the Internet as an important tool, with its website being one of the five most popular in Ukraine both preceding and during the Orange revolution. ${ }^{18}$ Eventually, Pora was involved in organizing protests, combining new technology and traditional methods of organization in order to promote participation, as well as monitoring elites using a network of mobile phone users that allowed information to be transferred and updated instantaneously. ${ }^{19}$

In addition to activist networks, the Internet became an important tool for journalists. Ukraine's media environment was strongly influenced by the state. As this was not enshrined in the law, but instead occurred via what Joshua Goldstein describes as "self-censorship," online media, which were less expensive and less constrained, became a source for less biased, or antiregime, information. This began in the years before the Orange Revolution,

16. Michael McFaul, “Transitions from Post-Communism," Journal of Democracy 16, no. 3 (July 2005): 12.

17. Joshua Goldstein, "The Role of Digital Networked Technologies in the Ukrainian Orange Revolution,” Berkman Center Research Publications 14 (2007).

18. Vladyslav Kaskiv, Iryna Chupryna and Yevhen Zolotariov, "It's Time! Pora and the Orange Revolution in Ukraine," in Pavol Demeš and Joerg Forbrig, eds., Reclaiming Democracy: Civil Society and Electoral Change in Central and Eastern Europe (2007); Lucan Way, “The Real Causes of the Color Revolutions," Journal of Democracy 19 no. 3 (July 2008).

19. Goldstein, "The Role of Digital Networked Technologies in the Ukrainian Orange Revolution”; Taras Kuzio, “Oligarchs, Tapes and Oranges: 'Kuchmagate' to the Orange Revolution," Journal of Communist Studies and Transition Politics 23, no.1 (March 2007): 30-56; Pavol Demes and Joerg Forbrig, "Pora-"It's Time” for Democracy in Ukraine" in Revolution in Orange: The Origins of Ukraine's Democratic Breakthrough, (Washington, D.C., 2006). 
and indeed in 2000 the founder of one of the most important online news sources, Ukrainska Pravda, was murdered, apparently at the behest of the President of Ukraine. ${ }^{20}$ Far from stifling online journalism, however, this event seems to have made Ukrainians more aware of online media.

Activist networks functioning in part online, and online journalism from sources like Ukrainska Pravda, ensured that the information environment in Ukraine was more open than it would have been with only traditional media. This meant that when electoral fraud was perpetrated in the course of the 2004 presidential election, an infrastructure existed to publicize the fraud quickly. One of us has previously argued that major electoral fraud represents an experience of simultaneous abuse by the regime of all citizens, and that this can help solve collective action problems partially by lowering the anticipated costs of participation in protest because of a belief that others may be simultaneously planning on protesting. ${ }^{21}$ Thus one of the primary contributions of digital media to the Orange Revolution was to make certain that electoral fraud did become public, and to provide a platform for non-state narratives as the situation developed further.

\section{The Digital Media Environment in Ukraine Beyond the Orange Revolution}

The digital strategies that were so important during the Orange Revolution helped to lay the groundwork for the expansion of online media sources and strategies of digital activism that would be critical during the EuroMaidan protests. Online media continued to represent a key source of independent information, particularly during the second Yanukovych presidency. However, by 2013, the tools available had changed dramatically, and these changes provided new opportunities. The traditional media environment in Ukraine was remarkably similar in 2014 to the environment in 2004 in so far as much of the media was controlled-either explicitly or implicitly-by the state, with very little independent journalism in the mainstream media. ${ }^{22}$ As before, online media was the primary site for opposition-based information exchange. What was different was the emergence of social media.

There is some variation in estimates of Internet penetration in Ukraine. A 2013 Freedom House study estimates the Internet penetration rate in Ukraine to be approximately $42 \%$ based on data from the International Telecommunications Union, a rate which had been steadily increasing over the preceding decade. It also reported that at the time $82 \%$ of Ukrainian Internet users lived

20. Goldstein, "The Role of Digital Networked Technologies in the Ukrainian Orange Revolution."

21. The idea is that the impetus to protest-in this case being upset about electoral fraud-is being simultaneously shared by large proportions of the population, as opposed to other reasons one might be frustrated with the regime (such as being required to pay a bribe), for which there is no reason to believe others will choose to push back against the regime at the same time. Joshua A. Tucker, "Enough! Electoral Fraud, Collective Action Problems and Post-Communist Colored Revolutions," Perspectives on Politics 5, no. 3 (September 2007).

22. Michael McFaul, “Transitions from Post-Communism”; Taras Kuzio, “Oligarchs, Tapes and Oranges.” 
in urban areas, with an Internet penetration rate of only about $18 \%$ in rural areas, reflecting a significant rural/urban divide. A Gallup report based on a representative sample of face to face surveys in Ukraine in 2014 finds slightly different results. ${ }^{23}$ It reports that about half of Ukrainians had Internet access in their home. It also provides some further breakdowns by demographics. According to the Gallup study, 89\% of Ukrainians 15-24 years of age and 73.1\% of Ukrainian 25-34 years of age used the Internet for news at least weekly, suggesting that online news was incredibly important, especially for young people. The study also finds that just under half of Ukrainians had accessed a social media site in the preceding week. While we were unable to find these statistics broken down by region, the Gallup study does provide comparisons between Crimea and the rest of Ukraine. It reports similar levels of Internet penetration in Crimea as compared to the rest of Ukraine, as well as similar levels of social media use. Furthermore, in our own data analysis we found geolocated tweets during the protests originating from all over the country, including in both eastern and western areas. ${ }^{24}$

Overall Internet traffic statistics also suggest that social media are widely used in Ukraine. The most commonly visited social media site in the country, and the second most popular website in the country after Google, is VKontakte, a Russian social media site that is similar to Facebook. ${ }^{25}$ Facebook, however, was the primary platform for the discussion of political topics, and the number one source of visits to independent media sites from within Ukraine. ${ }^{26}$

Twitter was much less popular in Ukraine than Facebook. In 2012 the number of Twitter users in Ukraine was estimated at approximately half a million people, although other estimates were as low as under 300,000, in comparison to Facebook's over 3 million Ukrainian users. ${ }^{27}$ As Figure 1 illustrates, however, there was a spike in user account creation on Twitter in response to the beginning of the protests, suggesting that many Ukrainians may have joined Twitter precisely because of the protests. Similarly, Yandex has reported that the number of Ukrainian Twitter users more than doubled from July 2013 to July 2014. The primary reason for this increase is posited to be political, with

23. "Freedom on the Net: Ukraine" Freedom House, 2014, at www.freedomhouse. org/report/freedom-net/2014/ukraine (last accessed January 10, 2016); "Contemporary Media Use in Ukraine,” Gallup, 2014, www.bbg.gov/wp-content/media/2014/06/Ukraineresearch-brief.pdf (last accessed on January 10, 2016).

24. Joshua Tucker, Jonathan Nagler, Megan Metzger, Duncan Penfold-Brown and Richard Bonneau, "Big Data, Social Media and Protest: Foundations for a Research Agenda," in R. Michael Alvarez, ed., Data Analytics in Social Science, Government, and Industry (Cambridge, Mass., 2016): 199-224. Exploring regional variation in social media usage within Ukraine would be an interesting area for future research.

25. Ol'ga Minchenko, "Vzhe 3 mil'iony ukraintsiv korystuiutsia Facebook," Watcher, October 2013, at www.watcher.com.ua/2013/10/25/vzhe-3-milyony-ukrayintsiv-korystuyutsya-facebook/ (last accessed on January 10, 2016).

26. Tetyana Bohdanova, "Unexpected Revolution: The Role of Social Media in Ukraine’s EuroMaidan Uprising” European View 13, no. 1 (2014).

27. Olga Rudenko, "Ukraine is not a Tweeting Nation Yet, but Give it Time," Kyiv Post, April 5, 2012, at www.kyivpost.com/article/guide/about-kyiv/ukraine-is-not-a-tweetingnation-yet-but-give-it-t-125565.html (last accessed January 10, 2016); Minchenko, "Vzhe 3 mil'iony ukraintsiv korystuiutsia Facebook.” 


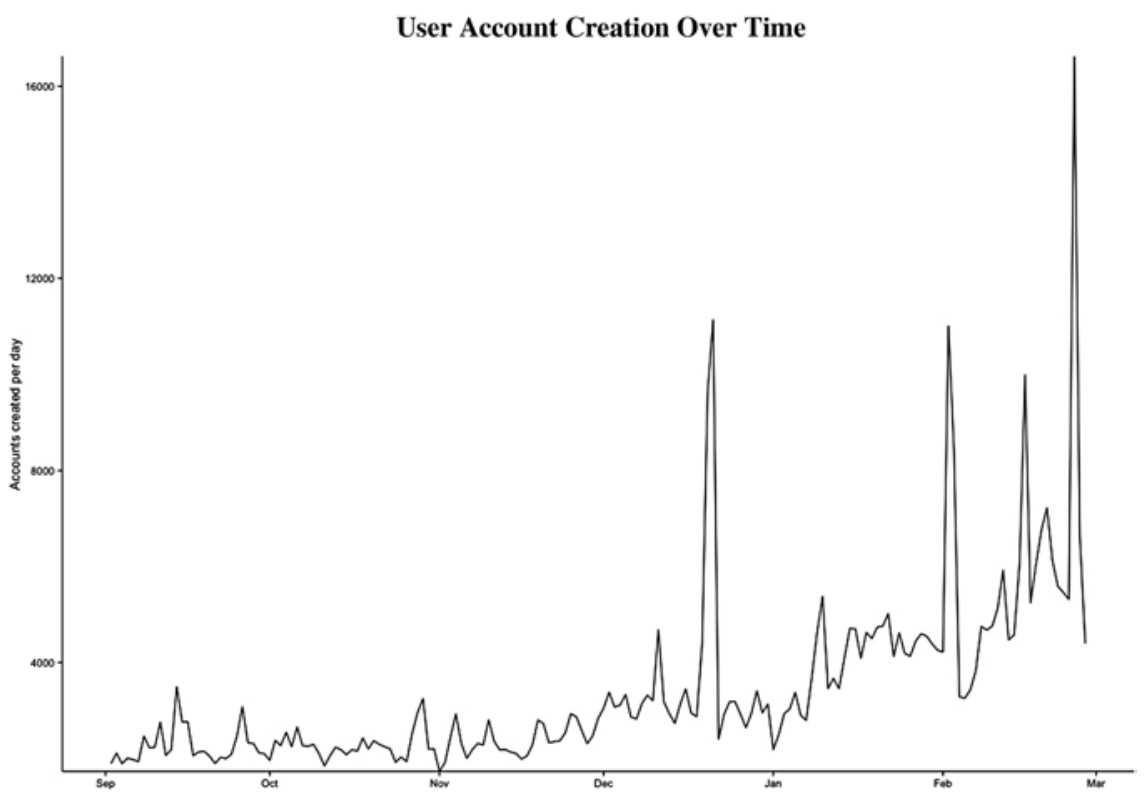

Figure 1. This figure plots the number of Twitter accounts created by day from September 2013-March 2014 in a dataset of Tweets collected by the NYU Social Media and Political Participation (SMaPP) lab using the Twitter Search API and a set of keywords related to the protests. Each tweet provides metadata including the date of the account creation, which explains why despite the fact that Tweets were collected during the protests, account creation dates go back farther in time. It shows a marked increase in account creation during the protest period.

the most common hashtag from that period being the Ukrainian language version of the EuroMaidan hashtag. ${ }^{28}$

Beyond social media, online news outlets like Ukrainska Pravda had continued to develop after the Orange Revolution. Video streaming news, most particularly Hromadske TV, was also already in existence before the protests began. Hromadske TV was launched in the summer of 2013 by a group of professional journalists, many with significant TV news experience, in order to provide an independent video news source. ${ }^{29}$ Because these resources had been developed gradually, they were already well-positioned to function as information disseminators, and were already trusted. This, combined with social media, created an information environment that eventually made repression of protest coverage unsustainable.

28. Olena Sikorska, "Yandex Report: Twitter Usage in Ukraine,” Digital East Factor, November 24, 2014, at www.digitaleastfactor.com/yandex-report-twitter-usage-ukraine/ (last accessed January 10, 2016). Yandex is a Russian Internet company that is similar to Google, at www.yandex.com.

29. Joanna Szostek, “The Media Battles of Ukraine’s EuroMaidan,” Digital Icons: Studies in Russian, Eurasian and Central European New Media 11 (2014): 1-19. 
The key takeaway is that the digital media environment in Ukraine before the protests was already well established. Furthermore, Ukrainians were already both well-prepared to use these media sources to circumvent the largely state-driven mainstream media, and accustomed to using them to find and identify independent information. Additionally, over the course of the protests, Ukrainians engaged with these tools in increasing numbers, amplifying the network of users, and increasing the reach of these information sources.

Social media may have also played an important role in determining the manner in which the Euromaidan protests were organized. While the Orange Revolution was largely organized by parties and opposition organizations, EuroMaidan seems to have arisen without the explicit assistance of such groups. ${ }^{30}$ This was possible in part because of the way that social media allows for organization. As mentioned above, Mustafa Nayem posted a call to his Facebook wall for people to join him in the square. Olga Onuch finds, in fact, that his was not the only such message on Facebook. ${ }^{31}$ Two factors contributed to Nayem's (and others') ability to mobilize a large number of people without explicit organizational backing. The first is the ability to use social media to reach out not only to strong social ties, but weak ones as well. This was strengthened by Nayem's status as a public figure, and a well-known journalist who was more widely connected than the average user would be. The outcome was a relatively decentralized organizational process. While some existing organizations, particularly student groups, did become involved in organizing, there was never a single, central group or figure that emerged as the leader of the protests. In fact, protestors actively discouraged political party signs and banners at the protests in order to maintain a non-partisan, united front. ${ }^{32}$ On several days, political parties actually held separate protests with their supporters on an adjoining square. ${ }^{33}$

Additionally, the EuroMaidan protests took place outside of the context of elections. Because the Orange Revolution was responding to particular instances of fraud, there were very clear and specific, unified demands on the part of the protesters for a new round of free and fair elections. EuroMaidan, on the other hand, while initially focused on the issue of the EU Association Agreement, eventually grew to encompass disparate demands including early elections, the resignation of the government and the president, and a return to the post-Orange Revolution constitution. This meant that the character of the protests was less unified, which was compounded by the fact that social media allows for the formation of cooperative networks across individuals who may differ greatly in ideology but be temporarily united for a single purpose.

30. Nadia Diuk, “The Maidan and Beyond: Finding Ukraine,” Journal of Democracy 25, no. 3 (2014): 83-89.

31. Olga Onuch, “'Facebook Helped Me Do It': Understanding the EuroMaidan Protestor 'Tool-kit,"' Studies in Ethnicity and Nationalism 15, no.1 (2015): 170-84.

32. Nadia Diuk, "The Maidan and Beyond."

33. Male, twenties, interview, Kiev, Ukraine, July 14, 2014; Female, twenties, interview, Kiev, Ukraine, July 25, 2014. 
This is often considered to be a shortcoming of social media driven movements: they cohere briefly but fail to persist. ${ }^{34}$ It is worth noting however, that there have been moments in history where change has been driven by a unity of purpose without a unity of ideology. Consider the relationship between pacifists like Martin Luther King Jr. and activists much more willing to use violence, like the Black Panthers or the Nation of Islam, during the American Civil Rights movement. Similarly, the original anti-communist "umbrella movement" in eastern Europe often brought together very disparate groups united by little more than a shared desire to bring about the end of the communist regime. In each case, these groups were not united in ideology, nor even in the final outcome they hoped to achieve, but they cooperated at key moments in order to achieve joint goals. Social media may allow for disparate individuals with similar goals to connect more easily, and perhaps with less potentially divisive conflict between organizations struggling for dominance.

\section{Social Media and EuroMaidan}

To reiterate, the extant literature suggests three important mechanisms by which social media could affect protest participation and development: by providing tools for organizing protests; by facilitating the spread of information related to protests; and by building networks that could sustain the protest movement. In this section, we explore the evidence to date in each of these areas.

\section{Organization and Mobilization}

We begin with probably the most direct role for social media, which is in organizing protests and mobilizing participation. While we may never know the precise direct effect of social media on motivating participation, in survey research conducted during the protests, Onuch found that $37.2 \%$ of people reported coming to protest, at least in part, as a result of reading on Facebook that their friends were going. Facebook was the largest single way that people heard about the protests except for the combined category of radio and television. ${ }^{35}$ Furthermore, $12.8 \%$ of Onuch's survey respondents reported receiving an invite on VKontakte. This also represents only a direct effect. Elihu Katz and Paul Lazarsfeld suggest a two-step model of information transmission, whereby information is transmitted from the mass media to key individuals who then spread this information more widely, beyond those who have actually been exposed to the media directly. ${ }^{36}$ Goldstein applies this to the context of digital media, emphasizing that particularly where Internet penetration is lower, this two-step information pathway allows information to flow directly

34. Gladwell, "Small Change”; Morozov, "The Net Delusion."

35. Olga Onuch, "EuroMaidan Protests in Ukraine: Social Media Versus Social Networks," Problems of Post-Communism, 62, no. 4 (July/August 2015): 217-35.

36. Elihu Katz and Paul F. Lazarsfeld, Personal Influence: The Part Played by People in the Flow of Mass Communications (Glencoe, IL, 1955). 
from digital media, and then be passed on to others who do not access the information directly. ${ }^{37}$ What we can learn from the data thus far is simply that social media was one important way that people decided to come out and protest. $^{38}$

Throughout the protests, social media continued to be used for organizational purposes. Facebook seems to have been the primary site on social media for the organization and coordination of resources and events, although Twitter and VKontakte also played a role. ${ }^{39}$ Organization on Facebook was apparently comprised of a central Facebook page, the main EuroMaidan page, and a number of smaller pages geared at particular organizational purposes. The main EuroMaidan page garnered an extraordinary number of followers, setting a record for its growth in followers for Ukraine..$^{40}$ Within two weeks, the page had over 125,000 followers, and these numbers continued to grow over the course of the protests. ${ }^{41}$ This page functioned as a clearinghouse for news and information about the protests, and as the main site for general information. The site posted everything from links to news about the protests to maps of where to get free tea and coffee on the freezing Kiev streets.

Other pages developed to serve more specific purposes, and to fill particular organizational needs. GetToMaidan, for example, was a page designed specifically for the coordination of carpools to the square..$^{42}$ Users could post their names, phone numbers, from where they were coming and the number of seats they had in their car. The page was also sometimes used to coordinate transportation of goods to protestors. Other pages provided information for people in need of legal services or helped to coordinate medical supplies and put out calls to doctors in order to help get assistance where it was needed.

One strategy that proved remarkably successful during the Ukrainian protests was crowdsourcing, as well as crowd funding for protest needs. The main EuroMaidan Facebook page often posted updates on the current needs of those on the square, and in interviews conducted in Kiev in the summer of 2014, participants suggest that once those needs were posted they were almost always filled immediately. Protestors even managed to collect sufficient donations to construct a field hospital, after police started arresting protesters who arrived at emergency rooms with certain types of injuries. ${ }^{43}$

37. Goldstein, “The Role of Digital Networked Technologies in the Ukrainian Orange Revolution."

38. An interesting subject for future work would be to try to estimate the way that this social media channel interacted with other aspects of individuals' decision making processes.

39. Bohdanova, “Unexpected Revolution,” 133-42.

40. Facebook, s.v. "EuroMaydan” at www.facebook.com/EuroMaydan/ (last accessed January 10, 2017).

41. Joshua Tucker, Megan Metzger, Duncan Penfold-Brown, Richard Bonneau, John Jost, and Jonathan Nagler, "Protest in the Age of Social Media: Technology and Ukraine's EuroMaidan," Carnegie Reporter 7, no.4 (Fall 2014), at www.medium.com/carnegie-corporation-international-peace-and/protest-in-the-age-of-social-media-7ae9fd940b06\#. c6j03fq0k (last accessed on January 10, 2016). As of October 2015, it had over 300,000 followers.

42. This Facebook page has since been removed (last accessed September 2014).

43. Male, forties, interview, Kiev, Ukraine, July 24, 2014. 
Facebook, as well as websites such as helpEuroMaidan.info, were used for this coordination. ${ }^{44}$

In contrast to Facebook, Twitter seems to have been less central to the actual organization of protests and materials. Much of what was posted on Facebook was cross-posted to Twitter, and often included hashtags indicating the organizational purpose of the tweet (for example \#gettomaidan). Nonetheless, the research conducted thus far suggests that actual organization of events and mobilization of resources happened more prominently on Facebook.

A final point to note about the organization of these protests is that we are only able to observe the public behavior of individuals. Certainly, we know that this public behavior is critical. Public social media activity signaled the level of support that the protests had, helped get specific needs for resources out to a wider audience, and announced important events to the public. Interviews conducted in the summer of 2014 in Kiev, however, suggest that users also exploited the networked component of Facebook in order to coordinate even among smaller groups, or to coordinate activities that could potentially get them into trouble. For these purposes, Facebook messenger allowed users to exploit the capacity of Facebook for easy, networked communication, but in a private way. Additionally, there seemed to be important linkages between online and offline mobilization. For example, one man who helped to crowd fund materials for the construction of a field hospital via Facebook reported that after some initial problems, those collecting donations decided to insist on actually receiving every donation in person for security reasons, despite organizing donations via social media. Further exploration of the relationship between these online and offline processes is an important question for future work. The history of Zello and EuroMaidan is similarly interesting. Zello (https://zello.com) essentially turns a phone into an audio walkie-talkie (and thus creates no permanent content), but can encompass hundreds of people in a group conversation. According to Zello's founder Alexey Gavrilov, at the height of the EuroMaidan protests he repeatedly received requests from Ukraine to increase the size of a group above the then-current 300-member maximum, and Zello responded by increasing the maximum to 1000 members. ${ }^{45}$

\section{Information}

Domestic Information Dissemination. Organization and the coordination of resources clearly represent one of the most important ways that social media was used during the protests. Beyond organization, however, social media also served as an information source. As mentioned above, one of the

44. Carola Frediani, "How Ukraine's EuroMaidan Revolution Played Out Online," TechPresident, February 28, 2014, at www.techpresident.com/news/wegov/24790/howEuroMaidan-play-out-online (last accessed on January 10, 2017).

45. Remarks by Alexey Gavrilov at an April 2, 2015 panel at University of Texas, Austin on Social Media and Digital Dissent: A Roundtable Discussion, http://calendar.utexas.edu/ event/social_media_the_dynamics_of_dissent\#.WIgblrYrLUo (last accessed January 11, 2017). 
roles played by the main EuroMaidan Facebook page was the dissemination of information. Most of this information was in Ukrainian or Russian and was directed at informing a domestic audience about the ongoing protests. This was also a role played by online media sources such as Ukrainska Pravda, and by streaming video sites such as Hromadske TV, which served to provide ongoing live coverage in the local language.

It is also in this area that Twitter emerges as a much more important platform. Our research at the NYU Social Media and Political Participation (SMaPP) lab demonstrates that activity on Twitter tracks extremely closely with key events on the ground, with activity spiking in response to changes in the offline situation. ${ }^{46}$ Moreover, after the police raid on the protest camp in early December, Twitter was used as a tool to disseminate current information to the domestic audience. ${ }^{47}$ During periods of crisis, we found spikes particularly in Tweets sent in the local language, suggesting that communication was directed at locals. Such patterns suggest that Twitter provided information that helped people decide whether to protest, and also to understand what was happening even if they were not themselves able to go to the square. ${ }^{48}$

Additionally, social media was able to provide a source of information that was largely uncontrolled by the state, whose content could come from protestors on the ground, allowing them to frame their own narratives about what was happening. In a piece in Forbes magazine, Greg Satell suggests that the speed of social media contributes to its ability to overcome the constraints placed on traditional media by state control. ${ }^{49} \mathrm{He}$ argues that information can be traded so quickly on social media that the information is already public knowledge before those who might repress it are able to act. This also seems to have changed the dynamics of information exchange domestically in important ways, as we will explore in greater depth when discussing the media later in this article.

International Information Dissemination. Beyond the domestic audience in Ukraine, social media (particularly Twitter) were able to play key roles in spreading information about the protests abroad. Our research at the SMaPP lab also revealed that a significant portion of Tweets during the protests were in English (in addition to substantial numbers in both Russian and Ukrainian). ${ }^{50}$ Early in the protests, $69 \%$ of geolocated users were tweeting

46. Tucker, et al., "Big Data, Social Media and Protest"

47. Megan MacDuffee Metzger, "As Police Raid Protests in Ukraine, Protestors Turn to Twitter and Facebook," Monkey Cage Blog of the Washington Post, December 11, 2013, at http://www.washingtonpost.com/blogs/monkey-cage/wp/2013/12/11/as-police-raidprotests-in-ukraine-protesters-turn-to-twitter-and-facebook (last accessed on January 11, 2017) .

48. Ibid.

49. Greg Satell, "If You Doubt That Social Media Has Changed the World, Take a Look at Ukraine," Forbes, January 18, 2014, http://www.forbes.com/sites/gregsatell/2014/01/18/if-you-doubt-that-social-media-has-changed-the-world-take-a-look-atukraine/\#308b682a699d (last accessed on January 10, 2017).

50. Tucker, et al., "Big Data, Social Media and Protest"; Metzger, "As Police Raid Protests in Ukraine, Protestors Turn to Twitter and Facebook"; Pablo Barberá and Megan MacDuffee Metzger, "How Ukrainian Protestors are Using Twitter and Facebook," Monkey Cage Blog of the Washington Post, December 4, 2013, at www.washingtonpost.com/ 
from within Ukraine, suggesting that much of the social media activity was domestic. ${ }^{51}$ Nonetheless, many of these users were tweeting in English in addition to Russian and/or Ukrainian, suggesting the goal of communicating with the international community about the situation in Ukraine.

In addition to ordinary users, several specialized groups formed dedicated to translating domestic news into English and other foreign languages in order to spread information abroad more effectively. These groups, like EnglishMaidan and EuroMaidanPR, operated via both Facebook and Twitter to disseminate protest news and information to the international community. ${ }^{52}$ The ability to do this is critical, as international pressure can often play a role in the success or failure of anti-government movements. Perhaps in part because of the mass of information about the protests available on social media, foreign governments did begin to pressure the Ukrainian government, and solidarity protests were held in cities across the world to promote the cause of the protesters. ${ }^{53}$

On the other hand, in March, after Yanukovych had fled and as the situation in Crimea was evolving, Russia blocked the VKontakte pages for several pro-EuroMaidan groups as well as for Pravi Sektor, a far right Ukrainian political party. ${ }^{54}$ The pages were only blocked in Russia, but this is another clear signal of the importance that transmission of information across international borders can have. At least to the Russian government, the access to this foreign information was likely viewed as potentially damaging enough to be worth censoring.

Another benefit of digital media is its ability to engage the diaspora, as well as the rest of the international community, in events that are happening far away from them in physical space. Around the world, solidarity protests were organized largely by the Ukrainian diaspora but with the support of many non-Ukrainians as well. ${ }^{55}$ In January 2014, a group of diaspora Ukrainians organized a Twitter storm on social media (an event where during a defined period of time people all tweet using the same, pre-chosen hashtag). The purpose of a Twitter storm is to raise the profile of an issue and to call international attention to it. Ukrainians managed to make \#digitalmaidan one of the top trending hashtags on Twitter during the period of the Twitter storm. ${ }^{56}$ Thus, digital media served to raise awareness in the international community

blogs/monkey-cage/wp/2013/12/04/strategic-use-of-facebook-and-twitter-in-ukrainianprotests (last accessed on January 11, 2017).

51. Pablo Barberá and Megan MacDuffee Metzger, "How Ukrainian Protestors are Using Twitter and Facebook."

52. Female, thirties, interview, Kiev, Ukraine, July 22, 2014.

53. Olena Goncharova, "Ukrainians Find Help Abroad in their Struggles," Kyiv Post, November 28, 2013, at http://www.kyivpost.com/article/content/ukraine/ukrainiansfind-help-abroad-in-their-struggles-332446.html (last accessed on January 11, 2017).

54. Dan Pototsky, "Social Media Groups Affiliated with Ukraine Blocked in Russia," Russia Beyond the Headlines, March 13, 2014, at www.rbth.com/science and_tech/2014/03/13/social_media_groups_affiliated_with_ukraine_blocked_in_ russi_35045.html (last accessed on January 11, 2017).

55. Goncharova, "Ukrainians Find Help Abroad in their Struggles."

56. Tetyana Lokot, "Ukrainian \#DigitalMaidan Activism Takes Twitter's Trending Topics By Storm,” Global Voices Online, January 27, 2014, at www.globalvoices.org/2014/01/27/ 
of events in Ukraine, but also provided an opportunity for those outside of Ukraine to become involved in the protests without being physically present.

Traditional Media and Digital Media. Of course, digital media interacts with and is influenced by "traditional" forms of media. The "old media" environment affects the impact of social media, not the least by providing content that can be shared on social media. At the same time, social media may also be able to affect the behavior of the old media. Thus, in the following section, we explore the interaction of social media with more traditional media sources.

After the Orange Revolution, Ukraine experienced a brief period of relatively free media, but by the time EuroMaidan emerged in the fall of 2013, Ukraine was ranked only 126th out of 179 countries on the Press Freedom Index and the 2013 Freedom House report considered Ukraine's press as "not free." 57 Most of the traditional media in Ukraine was owned by powerful oligarchs, and almost all of these economic elites had ties to the Yanukovych regime. Despite exerting a high degree of control over television news (the most common news source for Ukrainians before the protests), online journalism had remained mostly uncensored and independent, perhaps because Yanukovych did not believe that his core constituency was exposed to such sources. ${ }^{58}$

The importance of online media increased dramatically over the course of the protests. Unique visits to Ukrainska Pravda, for example, tripled during this period. ${ }^{59} \mathrm{By}$ the spring of 2014, more Ukrainians were getting their news from Internet sources than from any other source besides television. ${ }^{60}$ When gathering information about the protests specifically, however, a survey found that, for those in urban areas between the ages of 15 and 54, the Internet was the main source of information about the protests with over $83 \%$ of this demographic following the protests online. ${ }^{61}$

This centrality of new media impacted the overall media environment in several important ways. First, as discussed previously, social media was used to disseminate information about the protest to a wider domestic and international audience. While some of this information was user-created content, or derived from new media sources, this mechanism also served to disseminate traditional media to wider audiences, creating an interaction between traditional and new media, where new media platforms could provide an opportunity for traditional media to be seen by more people. ${ }^{62}$

Secondly, while traditional media sources could skew reporting of the protests in order to cast the protests in a negative light, many of the traditional means of media distortion were difficult to sustain in an environment where both independent online sources and any individual at the protest had

ukrainian-digitalmaidan-protests-twitter-trending-topics-storm/ (last accessed on January 11, 2017).

57. Sergii Leshchenko, "The Maidan and Beyond: The Media's Role," Journal of Democracy 25, no. 3 (July 2014): 19-34; “Contemporary Media Use in Ukraine,” Gallup.

58. Leshchenko, "The Maidan and Beyond."

59. Ibid.

60. "Contemporary Media Use in Ukraine," Gallup.

61. Szostek, "The Media Battles of Ukraine’s EuroMaidan.”

62. Tucker et al., "Protest in the Age of Social Media." 
the ability to contradict the coverage, and have that contradiction seen by a wide audience. As Joanna Szostek points out, "little that happened on or around Maidan could escape being captured and disseminated, visually or verbally, by the giant 'public eye' created by thousands of smartphones."63 The increasing popularity of the Internet and new media gave these thousands of smartphones an audience, and the existence of independent, online journalistic sources that could pick up on their experiences and report them gave them legitimacy.

Szostek argues that one of the key features of the protest movement was the "blurring of boundaries between journalism and activism." ${ }^{44}$ In an environment where the mainstream media was controlled by the state, independent journalism is, in and of itself, activism. To put it another way, protests with key social media components challenge the boundary between citizens and journalists. Monitoring of the mainstream media was accomplished not only by professional, independent journalists, but also by the masses of individual protestors all contributing their content to the giant crowd-sourced media machine that social media can become during a crisis. Digital media thus disrupted the hierarchy of information that exists in traditional media environments.

One outcome of this monitoring was to force the media's hand in covering the protests themselves. Faced with the prospect of losing legitimacy, mainstream media sites began to adjust the coverage that they showed of the protests. ${ }^{65}$ Indeed, the largely state-backed media covered the protests in a reasonably positive light for significant periods. Interviews with TV station managers (including Inter which was owned by Yanukovych's own chief of staff) suggested that their shift in coverage was in direct response to an understanding of the impact that access to new media had on their ability to manipulate viewers. ${ }^{66}$ Alternative information sources, in other words, forced traditional information sources to adjust their coverage or lose their influence. ${ }^{67}$

The final impact of new media on the domestic media environment was its ability to change the informational environment in a way that seems to have altered the incentives of important economic players. As mentioned above, much of the traditional media in Ukraine was controlled by powerful economic elites, oligarchs who typically have strong relationships with the state. Nonetheless, Yanukovych had a commitment to maintaining the power of a small group of particularly close associates, and the way that he approached this negatively affected some of the key oligarchs in the country, including those in powerful positions in the media. Many of these oligarchs began to fear that they would lose their privileged position relative to those close to Yanukovych. ${ }^{68}$ The level of support for the regime from high ranking economic

63. Szostek, "The Media Battles of Ukraine’s EuroMaidan.”

64. Ibid.

65. Leshchenko, “The Maidan and Beyond”; Szostek, “The Media Battles of Ukraine’s EuroMaidan.”

66. Leschhenko, "The Maidan and Beyond."

67. Ibid.

68. Serhiy Kudelia, “The Maidan and Beyond: The House that Yanukovych Built," Journal of Democracy 25, no. 3 (July 2014): 52-57. 
elites was thus perhaps more tenuous than it seemed. Nonetheless, new media had an impact here as well.

A number of observers noted that in providing positive coverage for the protests, oligarchs seemed to be hedging their bets against the potential future. ${ }^{69}$ Szostek, however, points out that the only reason it was necessary to hedge their bets was because continuing to tow the government line would not have been risk free, and this may in part have been a result of the government's message being consistently monitored by new media. ${ }^{70}$

The Yanukovych government does seem to have made some attempts to control online media, although these efforts appear to have been relatively sporadic. These included the use of "bots" (automated accounts run by computer programs) or posting propaganda websites designed to look like opposition sites such as Ukrainska Pravda. ${ }^{71}$ Overall, however, the government does not seem to have succeeded on a large scale at controlling information flow online. On the other hand, some activists do seem to have been targeted for their online activity. According to Freedom House, documents surveilling opposition actors' social media activity were found in Yanukovych's residence after his government was replaced. They further report over 150 cases of journalists or bloggers being assaulted during EuroMaidan. Thus, although the government seems to have failed to control information flow online, there certainly were repercussions to online activity, particularly for prominent actors. ${ }^{72}$

\section{Network Persistence and Building Civil Society}

One criticism of the role of social media in protests is that it does not develop the sorts of organizations that have historically led to the persistence of movements, the development of civil society, and long-term change. In the Ukrainian case, it is relatively early to assess the movement's persistence, and yet there are some early signs suggesting that the protest networks, developed partially on social media, will persist and evolve. Dickinson argues, in fact, that the protest networks have remained incredibly durable and adapted to changing on-the-ground situations in order to fulfill new roles. ${ }^{73}$ She points out that there has been a seamless transition among social media networks "from gathering support for protests ... to monitoring the actions of the in-

69. Matt Robinson and Pavel Polityuk, "Hedging their Bets, Ukraine's Oligarchs Sit above the Fray,” Reuters, December 5, 2013, http://uk.reuters.com/article/uk-ukraine-oligarchs-idUKBRE9B40MQ20131205 (last accessed on January 11, 2017).

70. New media may also have provided the oligarchs with a clear and cogent signal about the level of support that the opposition enjoyed among the population. At the end of the day, to the extent that oligarchs are economic opportunists whose goal is to maximize their own wealth and power, and to the extent that the opposition looks better positioned to help them to do that, it is in the interest of the oligarchs to support them. When the possibility of opposition success seems real, shifting support or at least attempting to play both sides becomes an optimal strategy.

71. Freedom House, "Freedom on the Net: Ukraine 2014," at www.freedomhouse.org/ report/freedom-net/2015/ukraine (last accessed January 11, 2017).

72. Ibid.

73. Jennifer Dickinson, "Prosymo Maksymal'nyi Perepost! Tactical and Discursive Uses of Social Media in Ukraine’s EuroMaidan,” Ab Imperio 3 (2014): 75-93. 
terim government ... to sharing geolocation analyses for videos uploaded to VKontakte by Russian soldiers suspected of firing into Ukrainian territory and crowdsourcing clothing and supplies for the Ukrainian army."74

Some of this has happened through the formation of new groups based on preexisting networks, but in other cases existing groups have simply transformed their purpose. Facebook pages like the main EuroMaidan page now post continuous updates about the situation in the east, ongoing political circumstances in the country, and monitor politicians' behavior. In interviews conducted in Kiev during the summer of 2014, we were told that one place where the transition has been relatively straightforward is among groups who worked to crowdsource resources and supplies during the protests. ${ }^{75}$ Several of these groups have now transitioned to crowdsourcing supplies for the Ukrainian army. ${ }^{76}$ EuroMaidanPR, which served to translate news about the protests into English and other languages, transitioned to reporting on the current situation in Ukraine, and (at the time of this writing) continues to regularly post Ukrainian news and updates in English, in particular monitoring Russian reporting on the situation in Ukraine.

Of course, early signs about the persistence of these networks must be tempered by the fact that the ongoing crisis in the east is not completely unconnected to the original protests themselves. These groups may thus not perceive that their mission has truly changed. Nonetheless, what we know so far suggests that the networked connections that emerged on social media during the protests may in fact persist and have the potential to develop into more traditional civil society organizations over time.

\section{Outstanding Questions About Digital Media and EuroMaidan}

Given the early state of research on the topic, there are still a number of outstanding questions related to digital media and EuroMaidan, as well as broader questions about the EuroMaidan movement that may be able to be answered in part with the help of social media data.

\section{From Online to Offline Behavior}

Although we have learned much about some of the strategies that people used on social media during the protests; how elites participated online; and the ways in which digital media interacted with traditional and mainstream media, we do not yet have a clear understanding of the direct relationships between online and offline behavior. Some early survey research hints at this, but in moving forward it will be important to try to establish what the precise connection is between what individuals do online and what they do offline. Can we use social media data to predict offline participation? Is certain

74. Ibid.

75. Male, forties, interview, Kiev, Ukraine, July 14, 2014.

76. Matthew Gault, "Ukraine is Crowdfunding its Army, but Popular Fundraising has a Downside,” July 13, 2014, at http://warisboring.com/ukraine-is-crowdfunding-its-armyf819fa24353\#.pbc9xunj5 (last accessed on January 11, 2017). 
information more motivating than others? Are there certain types of networks that will tend to encourage participation and vice versa?

Relatedly, we do not yet know what makes certain types of social media appeals more successful than others. To the extent that online mobilization efforts seem to bring people into the streets, what factors contribute to this process? Are users motivated by those closest to them in their network, by important public figures, or by some other factor? Is it the content of appeals or the network through which they are transmitted, or both, that matters? Here, existing social science theory on protest can help us to develop hypotheses, but we will need to find innovative ways to test these hypotheses given the difficulty of observing the direct relationship between online and offline behavior.

In addition to the connection between on- and offline behavior for protestors, we lack sufficient information about the effect of uniquely online action (like Twitter storms) on the outcome of protests. Evidence so far has suggested that social media changed the informational environment in important ways, but it has not yet been able to demonstrate a direct connection between online action and offline change. Understanding these relationships more precisely will be an important question for future research.

\section{The State and Social Media}

Another open question in the Ukrainian case is about the role of the state, and in this case also the role of the Russian state. From previous protests we know that states can hire people, or deploy "bots", in order to boost their presence in online discourse. ${ }^{77}$ Thus far, no work has been done evaluating whether this happened in the Ukrainian case. Given what we know about Yanukovych's perspective on the Internet, it seems unlikely that he would have been easily able to mobilize large-scale social media support domestically. Indeed, the only sign that the government (allegedly) actively attempted to intervene using digital media suggests that they were relatively clumsy at operating within a digital framework. More specifically, in January 2014 people in the vicinity of Independence Square, where the protests were being held, received a text message that read: "Dear subscriber, you are registered as a participant in a mass disturbance." Despite the ominous, Orwellian tone of the message, it seems that the cell phone operators did not cooperate with the government, therefore, ensuring no resulting consequences. ${ }^{78}$

It remains unclear whether the government did much behind the scenes to try to disrupt the digital narrative. Russia, however, is known to have a

77. BBC News, March 8, 2012, “Russian Twitter Political Protests' Swamped by Spam,” http://www.bbc.com/news/technology-16108876 (last accessed January 25, 2017); Entwickelr.de, June 30, 2014), "Turkeys Twitter-Bot Army and the Politics of Social Media," at https://entwickler.de/online/webmagazin/\%20/turkeys-twitter-bot-army-and-the-politics-of-social-media-1153.html (last accessed January 25, 2017).

78. Tyler Lopez, “How Did Ukraine’s Government Text Threats to Kiev’s EuroMaidan Protestors?,” Slate, January 24, 2014, at www.slate.com/blogs/future_tense/2014/01/24/ ukraine_texting_euromaidan_protesters_kiev_demonstrators_receive_threats.html (last accessed January 11, 2017). 
successful infrastructure for this sort of behavior, and might have lent assistance. ${ }^{79}$ In general, the government response is under-studied in these protests, and a study of how the government responded and how activists online reacted to government action would be an important contribution to the literature.

\section{Persistence}

Above, we presented some evidence of the persistence of protest networks after the end of the protests. This evidence, however, is relatively preliminary. We may not know for several years whether these networks persist and/or come to resemble traditional civil society organizations. Further, some of the ways in which persistence seems to be occurring, for example through crowdfunding for the army, may have unclear impacts on the incentives of politicians. ${ }^{80}$ Keeping track of the way that this develops over time will be critical to understanding the long-term impact of the movement.

In the same vein, we still know very little about the relationship between the protest movement and the ensuing crisis in Crimea and the eastern part of Ukraine. Deeper work on the way that networks have transitioned from working on issues of protests towards working on issues about the crisis and ongoing violence can help give us insight into the way that social media can make networks more flexible.

\section{Digital Media-Driven versus Traditional Protest}

A final important question concerns the long-term implications of protests becoming increasingly driven by digital media. Some observers, the mostoften cited being Malcolm Gladwell, have asserted that social media-driven protest is not real activism, and does not involve the sorts of durable networks that encourage people to take high risk action. He concludes rather dismissively that social networks are good primarily for trivial things that look good, but have very little real impact. ${ }^{81}$ What Gladwell and those who take up his position neglect is that while Facebook and other social media are indeed good at maintaining weak ties, they also include individuals' strong ties. So, rather than creating networks of loose connections, the better description may perhaps be a network of loose connections anchored by strong, trusted connections. What Ukraine has shown us is that these sorts of networks seem, in fact, to be able to motivate people to high risk action: recall that over $35 \%$ of those in the Onuch survey of protest participants said that they went to the protests at least in part because they saw on Facebook that friends or family were going. They seem to be able to achieve things that Gladwell asserted were

79. Sergey Sanovich, Denis Stukal, Duncan Penfold-Brown and Joshua Tucker, “Turning the Virtual Tables: Government Strategies for Addressing Online Opposition with an Application to Russia" (unpublished paper presented at the Society for Institutional and Organizational Economics, 2015).

80. Gault, "Ukraine is Crowdfunding its Army."

81. Gladwell, "Small Change." The precise example is Wall Street executives getting their phones back from teenage girls. 
impossible, like creating effective organizational structures for the coordination of materials. Perhaps this is because there is an interplay between online and offline action in a way that Gladwell did not anticipate. What is critical is that for the offline action to occur as it did, the online behavior seems, from the evidence we have so far, to have been an important component.

What is also certainly true is that this sort of movement looks different from many traditional movements. While evidence so far suggests that these networks can be more persistent and effective than some had speculated, we do not yet have an answer for what the long-term impact of such a shift in organizational strategy will be, and whether or not it will be permanent, or morph into something else that looks very different. One possibility, for example, is that these looser networks will be better at monitoring the state and making people aware of political situations in the country than those who organized the Orange Revolution were, perhaps because they are less directly connected to the state. Another possibility is that these networks will fall apart as soon as the crisis is over. Yet a third is that they will exist as loose networks which can be reactivated in crisis, but which will play little role in day-to-day politics. ${ }^{82}$ Only time, and continued study, will show what the real impact of such a new style of organization will be. What is certain, however, is that traditional organizing, without at least some use of social media, is probably becoming outdated.

\section{Conclusion}

There are several important takeaways from the existing research into the role of digital media during EuroMaidan. The first is that this group of protests puts to rest any lingering doubts that social media can be consequential in mobilizing and organizing protest. We may not yet understand the full impact of social media or the exact mechanisms through which it is impactful, but in this case the evidence is clear that social media was a key tool used for organizing, and that at least some of the efforts organized online would have been impossible or extremely difficult using traditional means of organization. The ability to accept donations online, to coordinate carpools across long distances, and to generate widespread shows of support from around the world are all hallmarks of the digital nature of the movement. The movement was largely leaderless, but not disorganized, ideologically diverse but not uncooperative, and, perhaps most importantly, it was able to topple the government.

A second takeaway is that digital networks, at least where they are largely uncensored by authorities, have the ability to do a great deal to circumvent a relatively repressive media environment, and even to force concessions from the mainstream media on their coverage of events. This suggests that in longer term, we are likely to see states attempt to exert more control on these types of media. ${ }^{83}$

82. It is probably worth asking, though, how different this is from many movements that existed in the pre-social media era as well.

83. It is important to note that some states, in particular China, are already quite good at controlling social and other digital media. It is not a given, however, that all states can 
The third takeaway is that the networks that emerged out of these protests appear to be much more durable than many expected. While there was a repurposing and reorientation to the ongoing crisis in the east, networks developed during the protests have persisted. In fact, their ability to shift focus towards roles more suited to the day-to-day politics of the state-monitoring presidential campaigns, tracking the behavior of politicians, or speaking out against biased news sources-looks a great deal like what we typically imagine civil society to be. True, for the most part, these are not organizations housed in brick and mortar buildings, but their success is not necessarily hindered by this fact.

The final takeaway is that-assumptions aside-we still know surprisingly little about social media-infused movements, and there is much work left to be done. We have laid out just a few of the outstanding questions above. As we continue to watch developments in Ukraine, it is how the movement evolves and adapts that will be the most telling for how we judge its long-term success.

or will control the opposition online. Instead, it is an open research question as to how different states will respond to different types of opposition. For some initial work in this regard, see: Sanovich et al., "Turning the Virtual Tables," who develop a three-fold classification of strategies employed by authoritarian (or competitive authoritarian) regimes to respond to online opposition. 